Part I: Northeast Asia 


\title{
Regulation on Navigation of Foreign Vessels: China's Practice
}

\author{
Keyuan Zou and Xinchang Liu
}

\section{Introduction}

China has been engaged in establishing various regulations on navigation of foreign vessels, as well as adapting existing rules to meet the requirements of international law of the sea. China has a systematic legal framework of basic rights and obligations of foreign vessels that includes regulations on port control, foreign vessel registration, protection of waterways, prevention of marine pollution, internal waters, maritime accidents and other related subjects. China's regulations on navigation of foreign vessels include both general rules governing foreign vessels, such as guidelines and principles for law enforcement and detailed and specific rules concerning the management of foreign vessels in different maritime zones. The first part of this chapter will focus on a general analysis of regulations on foreign vessels. The second and third parts will discuss innocent passage and archipelagic sea-lane passage respectively, and in the fourth part, we will discuss straits used for international navigation. In the last two parts, the discussion will focus on China's regulations concerning the exclusive economic zone (EEZ) and China's routeing system required by the International Maritime Organization (IMO).

\section{Regulations concerning Foreign Vessels}

\section{Basic Rights and Obligations of Foreign Vessels under Chinese Law}

China has enacted a series of laws and regulations governing the navigation of foreign vessels based on general international law, including the United Nations Convention on 
the Law of the Sea (LOSC), and domestic legislation such as the 1992 Law on the Territorial Sea and the Contiguous Zone, ${ }^{1}$ the 1998 Law on the Exclusive Economic Zone and the Continental Shelf, ${ }^{2}$ the 1982 Maritime Traffic Safety Law, ${ }^{3}$ the Regulations Governing Supervision and Control of Foreign Vessels, and the Rules for the Control of Non-Military Vessels of Foreign Origin Passing Through the Qiongzhou Strait. ${ }^{4}$ The laws and regulations articulate the basic rights and obligations of foreign vessels in different jurisdictional waters. For example, Article 8 of the Regulations Governing Supervision and Control of Foreign Vessels provides that the Harbour Superintendency Administration is fully authorized to detain a foreign vessel, or to order the vessel to stop sailing, to change route or to return to the port under any of the following circumstances: (1) unseaworthiness; (2) violation of Chinese laws and regulations; (3) involvement in marine accident; (4) non-payment of expenses to which the vessel is liable or failure to produce security required; or (5) other cases prohibiting the vessel from sailing. ${ }^{5}$ Article 9 further provides that 'vessels navigating in Chinese port areas and coastal waters shall not be engaged in activities endangering the national safety, rights and interests of the People's Republic of China and shall comply with regulations governing straits, waterways, routes and areas closed to navigation. ${ }^{6}$

\section{Port Control}

As for port control, the Regulations Governing Supervision and Control of Foreign Vessels give detailed provisions, as Article 5 provides that 'Upon arrival at the port, vessels shall immediately submit the Entry Report and other relevant forms for checkup; besides, vessels shall submit ship's papers and relevant documents for examination and be subject to inspections. Prior to leaving, vessels shall submit the Departure Report and other relevant forms for clearance examination and may only leave the port after

\footnotetext{
1 Law on the Territorial Sea and the Contiguous Zone, 25 February 1992.

2 Law on the Exclusive Economic Zone and the Continental Shelf, 26 June 1998.

3 Maritime Traffic Safety Law, 2 September 1983.

4 Rules for the Control of Non-Military Vessels of Foreign Origin Passing through the Qiongzhou Strait, 8 June 1964.

5 Regulations Governing Supervision and Control of Foreign Vessels, Article 8.

6 Ibid., Article 9.
} 
port clearance has been obtained.' It further stipulates that 'arms and ammunition on board are to be sealed up by the Harbour Superintendency Administration. Radiotelegraph transmitter, radio-telephone transmitter, signal rockets, flare signals and signal guns shall only be used in case of emergency, and a report shall be made to the Harbour Superintendency Administration immediately afterwards.' (Article 6) 'Shooting, swimming, fishing, setting off of firecrackers or fireworks and other actions calculated to endanger the order and security of the port shall be prohibited. ' (Article 7) 'In order to ensure the safety of the port and vessels, when ordered to shift berth or to sail ahead of or behind the schedule, vessels shall observe such orders as given by the Harbour Superintendency Administration.' (Article 22)

\section{Foreign Vessel Registration}

The Regulations of the People's Republic of China Governing the Registration of Ships ${ }^{7}$ is China's most important regulation on vessel registration. Article 2 of it provides that ' $[\mathrm{t}] \mathrm{he}$ following ships shall be registered in accordance with the provisions of these Regulations: (1) Ships owned by citizens of the People's Republic of China whose residences or principal places of business are located within the territory thereof; (2) Ships owned by enterprises with legal person status established under the laws of the People's Republic of China and whose principal places of business are located within the territory thereof, provided that foreign investment is involved, the proportion of registered capital contributed by Chinese investors shall not be less than 50 per cent; (3) Service ships of the Government of the people's Republic of China and ships owned by institutions with legal person status; (4) Other ships whose registration is deemed necessary by the competent authority of harbour superintendency of the People's Republic of China. Military ships, fishery ships and sports craft shall be registered in compliance with the provisions of the relevant laws and regulations.' Article 4 provides, 'A ship shall not have dual nationality. A ship registered abroad whose former registration of nationality has not been suspended or

\footnotetext{
7 Regulations of the People's Republic of China Governing the Registration of Ships, 2 June 1994 (Amended).
} 
deleted shall not be granted the Chinese nationality.' We can see that Chinese vessel registration is not open to foreign flag vessels. With very few exceptions only vessels owned by Chinese legal entities or nationals, or bareboat chartered to them, can be registered in China and fly the Chinese flag. ${ }^{8}$

According to the Regulations, the port where a ship is registered shall be the port of registry of the ship. The owner of a ship may choose a port closer to his residence or his principal place of business as the port of registry, but not allowed to choose two or more ports as the port of registry. (Article 9) Each ship shall have only one name. The name of a ship shall be checked and approved by the ship registration authority at the port of registry. A ship's name shall not be the same as any of those that have already been registered, neither in wording nor in pronunciation (Article $10)$.

\section{Shipping of Dangerous Wastes}

China ratified the Basel Convention on the Control of Transboundary Movements of Hazardous Wastes and Their Disposal on 17 December 1991, and promulgated certain rules on this issue. According to Article 39 of the Marine Environmental Protection Law, it is prohibited to transship dangerous wastes through internal waters or territorial seas of China. Prior written permit must be obtained from the administrative department in charge of environment protection under the State Council for shipping any dangerous wastes through the other sea areas under the jurisdiction of the People's Republic of China. ${ }^{9}$ In case of the movement of any dangerous wastes through the sea areas under the jurisdiction of the People's Republic of China in violation of the provisions above, the State administrative department in charge of maritime affairs shall order the vessel illegally shipping the dangerous wastes to withdraw from the sea areas under the jurisdiction of the People's Republic of China, and impose a fine of no less than 50,000 yuan but no more than 500,000 yuan (Article 79).

\footnotetext{
8 http://www.nortonrosefulbright.com/knowledge/publications/13355/china-flag-vessels-an-overview.

9 Marine Environmental Protection Law, Article 39. 
Also, China promulgated the Supplementary Provisions to the "Interim Provisions on the Administration of Environmental Protection regarding the Import of Waste Materials" in $1996^{10}$ and issued the Administrative Provisions of the People's Republic of China on the Prevention and Control of Marine Environmental Pollution by Vessels and Their Operations in November $2010 .{ }^{11}$

\section{Protection of Waterways}

The 1983 Maritime Traffic Safety Law provides that all personnel on vessels and installations must observe relevant rules and regulations concerning maritime traffic safety, follow the operating rules and ensure the safety of the vessels and installations in navigation, berthing and operations. ${ }^{12}$ Non-military vessels of foreign nationality may not enter the internal waters and harbours of the People's Republic of China without the approval of its competent authorities. However, under unexpected circumstances such as critical illness of personnel, engine breakdown or vessel distress including seeking shelter from weather, a vessel may enter China's internal waters or harbours as long as it makes an emergency report to the competent authority and obeys the authority's directions. Military vessels of foreign nationality may not enter the territorial waters of the People's Republic of China without the approval of the Government of the People's Republic of China (Article 11). Vessels of foreign nationality entering and leaving a harbour of the People's Republic of China, navigating or shifting berths in the harbour area, or approaching or leaving mooring points or loading spots outside the harbour must be navigated by a pilot designated by the competent authority (Article 13).

\section{Prevention of Marine Pollution}

As Article 5 of the Marine Environmental Protection Law provides, the State administrative department in charge of maritime affairs is responsible for monitoring

\footnotetext{
10 See http://english.sepa.gov.cn/Resources/laws/regulations/Solid Waste/200710/t20071022 111646.shtml.

11 See http://en.pkulaw.cn/Display.aspx?lib=law\&Cgid=141265. It came into effect on 1 February 2011.

12 Maritime Traffic Safety Law, Article 9.
} 
any marine environment pollution caused by non-military vessels inside the port waters and non-fishing vessels and non-military vessels outside port waters. The Department is responsible for the investigation and cleanup of pollution accidents. In the event of a pollution accident caused by a foreign vessel navigating, berthing or operating in waters under the jurisdiction of the People's Republic of China, inspection and handling shall be conducted on board the vessel in question. Where the pollution accident caused by a vessel results in fishery damages, the competent fishery administrative department shall be invited to take part in the investigation and handling (Article 5).

In 2015, China amended the Provisions of the People's Republic of China on the Administration of Emergency Preparedness for and Emergency Response to Vessel-Induced Pollution to the Marine Environment. ${ }^{13}$ These Provisions apply not just to vessels operating within the sea areas of China but also to national emergency preparedness for and emergency response to vessel-induced pollution accidents outside the sea areas of China, which have caused or may cause pollution to the Chinese sea areas.

\section{Maritime Accidents}

Specific regulations governing maritime accidents include the Regulations of the People's Republic of China on the Investigation and Handling of Maritime Traffic Accidents (1990), ${ }^{14}$ the Ship Safety Inspection Rules of the People's Republic of China (2009), ${ }^{15}$ and the Regulations of the People's Republic of China Governing Survey of Ships and Offshore Installations (1993). ${ }^{16}$

The Regulations of the People's Republic of China on the Investigation and Handling of Maritime Traffic Accidents (1990) provides that the harbour

\footnotetext{
13 Provisions of the People's Republic of China on the Administration of Emergency Preparedness for and Emergency Response to Vessel-Induced Pollution to the Marine Environment, 12 May 2015.

${ }_{14}$ Regulations of the People's Republic of China on the Investigation and Handling of Maritime Traffic Accidents, 3 March 1990.

15 Ship Safety Inspection Rules of the People's Republic of China, 30 November 2009.

16 Regulations of the People's Republic of China Governing Survey of Ships and Offshore Installations, 14 February 1993.
} 
superintendency agency of the People's Republic of China shall be responsible for implementing these Regulations (Article 2). The maritime traffic accidents referred to in these Regulations mean the following accidents happening to vessels and installations: (1) collision, strike or damage by waves; (2) hitting hidden rocks or running aground; (3) fire or explosion; (4) sinking; (5) damage or loss of machinery parts or important tools during a voyage which affects the vessel's seaworthiness; (6) other maritime traffic accidents which cause losses in property and human lives (Article 4).

The competent authority in China for the management of foreign vessels is the China Maritime Bureau (formerly known as Harbour Superintendency Administration) of the Ministry of Communications. It was restructured in 1999 to include the Bureau of Vessels Inspection. According to the recent restructuring program, twenty local maritime branches were set up directly subordinated to the Ministry of Communications. The Maritime Bureau is entrusted to have the following functions: (1) to supervise the implementation of marine traffic regulations by foreign ships; (2) to issue authorization to foreign ships to enter or depart from Chinese ports; (3) to appoint and arrange pilotage for foreign vessels which are permitted to enter or leave Chinese ports; (4) to supervise the technical status of foreign ships, and to maintain traffic order and safety; and (5) to investigate and handle issues arising from marine incidents. ${ }^{17}$

\section{Internal Waters}

There are three sets of laws and regulations governing the navigation of foreign vessels in the internal waters. These laws cover (1) sea port waters; (2) some strategic waterways, ${ }^{18}$ and (3) the Qiongzhou Strait. ${ }^{19}$ The management of foreign vessels in

\footnotetext{
17 See Zou Keyuan, 'Curbing marine environmental degradation: China's new legislation', International Journal of Marine and Coastal Law, 2001, p.355.

18 A strategic waterway is a narrow body of water on an important transportation route or sea lane.

19 Zou Keyuan, 'Navigation of foreign vessels within China's jurisdictional waters', Maritime Policy \& Management, 2002, 29:4, pp.351-374.
} 
the port waters is addressed above in the section on Port Control. .The Qiongzhou Strait will be discussed in Section IV on straits used for international navigation.

The general regulations governing China's waterways is the Regulation of the People's Republic of China on the Administration of Navigable Waterways. ${ }^{20}$ There are two regulations concerning the passage of merchant vessels through internal strategic waterways: the Lao Tieh Shan Channel and within the inner water area of the Encounter Rock in the Bohai Sea (or Bay). ${ }^{21}$ In 2000, China implemented two new rules in the Chengshanjiao Promontory which stands at the mouth of the Bohai Sea. Vessels on their way to Tianjin, Yantai, Qinhuangdao and Dalian usually have to go through this channel. It is the busiest sea route for sea transport and has more maritime accidents than any sea area in China. The Ship Routeing System consists of the traffic separation scheme, the inshore traffic zone and the precautionary area, ${ }^{22}$ and the Mandatory Ship Reporting System applies to fishing vessels that are 24 meters long or more, cargo ships weighing 300 tons or more and passenger ships. ${ }^{23}$ These two systems were approved by the IMO, and implemented on 12 January $2000 .^{24}$

\section{Innocent Passage}

The right of innocent passage guarantees the navigational rights of foreign vessels in China's territorial sea. The Declaration on China's Territorial Sea promulgated by China on 4 September 1958 stated, "no foreign vessels for military use and no foreign aircraft may enter China's territorial sea and the air space above it without the permission of the Government of the People's Republic of China. ${ }^{25}$ Although the

\footnotetext{
20 Regulation of the People's Republic of China on the Administration of Navigable Waterways, 27 December 2008.

${ }^{21}$ Zou Keyuan, Navigation of foreign vessels within China's jurisdictional waters, Maritime Policy \& Management, 2002, 29:4, pp.351-374.

22 Zou Keyuan, ibid., p.361.

23 Zou Keyuan, ibid., p.361.

24 Zou Keyuan, ibid., p.361.

25 Declaration of the Government of the People's Republic of China on China's Territorial Sea 1958.
} 
scope is specifically limited to vessels for military use, in practice, China recognized the right of innocent passage for merchant ships, provided that they are in compliance with relevant Chinese laws and regulations. The intention behind the Declaration at that time is clear: it was to deter U.S. warships, which supported logistically the Nationalist Chinese in Taiwan, from approaching the coast of mainland China. ${ }^{26}$

The spirit and content of the Declaration on innocent passage were endorsed in later Chinese laws and regulations. Article 11 of the Maritime Traffic Safety Law of the People's Republic of China provides, 'Military vessels of foreign nationality may not enter the territorial waters of the People's Republic of China without the approval of the Government of the People's Republic of China. ${ }^{27}$ In the Law of the People's Republic of China on the Territorial Sea and the Contiguous Zone, Article 6 provides that 'Foreign ships for non-military purposes shall enjoy the right of innocent passage through the territorial sea of the People's Republic of China in accordance with the law. Foreign ships for military purposes shall be subject to approval by the Government of the People's Republic of China for entering the territorial sea of the People's Republic of China.' 28 Article 7 further provides, 'Foreign submarines and other underwater vehicles, when passing through the territorial sea of the People's Republic of China, shall navigate on the surface and show their flag.' Article 8 provides, China 'has the right to take all necessary measures to prevent and stop non-innocent passage through its territorial sea. Cases of foreign ships violating the laws or regulations of the People's Republic of China shall be handled by the relevant organs of the People's Republic of China in accordance with the law.' Also, China 'may, for maintaining the safety of navigation or for other special needs, request foreign ships passing through the territorial sea of the People's Republic of China to use the designated sea lanes or to navigate according to the prescribed traffic separation schemes. The specific regulations to this effect shall be promulgated by the Government of the People's Republic of China or its competent authorities concerned.'(Article 9) 'In the case of

\footnotetext{
${ }^{26}$ Zou Keyuan, 'Innocent passage for warships: The Chinese doctrine and practice', Ocean Development \& International Law, 1998, 29:3, 195-223.

27 Maritime Traffic Safety Law of the People's Republic of China, Article 11.

28 Law of the People's Republic of China on the Territorial Sea and the Contiguous Zone, Article 6.
} 
violation of the laws or regulations of the People's Republic of China by a foreign ship for military purposes or a foreign government ship for non-commercial purposes when passing through the territorial sea of the People's Republic of China, the competent authorities of the People's Republic of China shall have the right to order it to leave the territorial sea immediately and the flag State shall bear international responsibility for any loss or damage thus caused.' (Article 10)

When China ratified the LOSC in 1996, it made the following statement with a view to innocent passage: 'The provisions of the United Nations Convention on the Law of the Sea concerning innocent passage through the territorial sea shall not prejudice the right of a coastal State to request, in accordance with its laws and regulations, a foreign State to obtain advance approval from or give prior notification to the coastal State for the passage of its warships through the territorial sea of the coastal State'. ${ }^{29}$

It is noted that there are different doctrines and practices on innocent passage for warships in the world community. Different countries may have different attitudes, and one country may have different attitudes during different historical periods. Also, judicial decisions on innocent passage, whether domestic or international, are rare, which adds more ambiguity in this area. ${ }^{30}$

\section{Hot Pursuit}

The right of hot pursuit is provided in Article 111 of the LOSC. In China's domestic law, the right of hot pursuit is consistent with the above article in general but not identical. Article 14 of Law of the People's Republic of China on the Territorial Sea and the Contiguous Zone stipulates, "The competent authorities concerned of the People's Republic of China may, when they have good reasons to believe that a foreign ship has violated the laws or regulations of the People's Republic of China, exercise the right of hot pursuit against the foreign ship. Such pursuit shall be commenced when the foreign

${ }^{29}$ Zou Keyuan, Innocent passage for warships, 195-223.

30 Zou Keyuan, ibid. 
ship or one of its boats or other craft engaged in activities by using the ship pursued as a mother ship is within the internal waters, the territorial sea or the contiguous zone of the People's Republic of China. If the foreign ship is within the contiguous zone of the People's Republic of China, the pursuit may be undertaken only when there has been a violation of the rights as provided for in the relevant laws or regulations listed in Article 13 of this Law. The pursuit, if not interrupted, may be continued outside the territorial sea or the contiguous zone until the ship pursued enters the territorial sea of its own country or of a third State. The right of hot pursuit provided for in this Article shall be exercised by ships or aircraft of the People's Republic of China for military purposes, or by ships or aircraft on government service authorized by the Government of the People's Republic of China."

Also, Article 12 of Law on the Exclusive Economic Zone and the Continental Shelf of the People's Republic of China provides, China "has the right to take necessary measures against violations of its laws and regulations in its exclusive economic zone and on its continental shelf and to investigate for legal responsibility according to law, and may exercise the right of hot pursuit."

There are some problems with China's above legislation concerning hot pursuit. Firstly, the specific reference of "the competent authorities" in Article 111 of the Convention should be defined case-by-case. Different states have different authorities regulating foreign vessels' navigation. Individual state need to make clear in its domestic law which are "the competent authorities" instead of use the same words in the Convention. In China, law enforcement in the sea is very complicated, more than one departments function in various ways to regulate navigation in the sea. Thus, it is necessary to define clearly "the competent authorities".

Secondly, as to the commencement of hot pursuit, a necessary constituent requirement of lawful hot pursuit is not provided for, that is, "The pursuit may only be commenced after a visual or auditory signal to stop has been given at a distance which enables it to be seen or heard by the foreign ship." ${ }^{31}$ The acknowledgement in advance,

\footnotetext{
31 Yu Mincai, 'The Implementation of the Right of Hot Pursuit and China's Maritime Law Enforcement', China Oceans Law Review, Vol.2005 No.1. p.403.
} 
as known as the signal to stop, is of considerable significance since pursuit is considered to have lawfully started only at the moment when a signal to stop is clearly given to the suspected vessel. ${ }^{32}$

Thirdly, there is a lack of provisions on continued pursuit after the hot pursuit undertaken by the pursuing ship or aircraft. ${ }^{33}$ Pursuit must be uninterrupted. Continuity of pursuit is the jurisdictional link that serves to keep the coastal state claim against the pursued vessel alive. Hot pursuit may therefore continue onto the high seas only so long as it is not interrupted. This requirement ensures that enforcement actions are not, due to misidentification, taken against the wrong vessel in violation of an innocent vessel's right to navigate freely on the high seas. ${ }^{34}$

Fourthly, China's jurisdiction within the contiguous zone is extended to cover "security" matters which is not included in the scope where hot pursuit can be exercised. ${ }^{35}$ This in fact gives the government more chances to exercise hot pursuit, which is not the original intent of the Convention.

It follows that China's laws on the right of hot pursuit is too general, disperse, and short of operability, inevitably bringing difficulties in marine law enforcement and affecting the efficiency of exercising hot pursuit. ${ }^{36}$

\section{Archipelagic Sea Lane Passage}

There is no legislation or regulation governing archipelagic sea lane passage in China's domestic law. China's state practice as regards national vessels operating in other state's archipelagic sea lanes is simple in theory but very complicated in practice. Theoretically,

\footnotetext{
32 Nicholas M Poulantzas, The Right of Hot Pursuit in International Law, p.204.

${ }^{33}$ Yu Mincai, 'The Implementation of the Right of Hot Pursuit and China's Maritime Law Enforcement', China Oceans Law Review, Vol.2005 No.1. p.403.

${ }^{34}$ Craig H. Allen, 'Doctrine of Hot Pursuit: A Functional Interpretation Adaptable to Emerging Maritime Law Enforcement Technologies and Practices', Ocean Development and International Law, Vol. 20, p.319.

35 Yu Mincai, 'The Implementation of the Right of Hot Pursuit and China's Maritime Law Enforcement', China Oceans Law Review, Vol.2005 No.1. p.404.

${ }^{36}$ Yu Mincai, ibid.
} 
China's position toward archipelagic sea lane passage is completely consistent with the LOSC. However in practice, there are numerous disputes in Xisha Islands (Paracel Islands) and the South China Sea.

China has no archipelagic waters as defined under the LOSC, however, China's Xisha Islands (Paracel Islands) was encircled with straight baselines. This results in many controversies in the international society. For example, the US protested that China would not be allowed to establish archipelagic straight baselines around the Paracel Islands according to the definition of archipelagos and archipelagic State under the LOSC. ${ }^{37}$ However, it is still debatable whether a continental State has the right to draw straight baselines for its mid-ocean islands or archipelagos. In practice, there are some countries using archipelagic straight baselines for their mid-ocean archipelagos, such as Ecuador, Denmark and Portugal. ${ }^{38}$

\section{Straits Used for International Navigation}

Article 43 of the LOSC is the mechanism by which straits used for international navigation are regulated by the transit passage regime provisions of Part III. Generally speaking, the LOSC sets, in Article 37, two standards defining the straits used for international navigation in that straits are "used for international navigation between one part of the high seas or an exclusive economic zone and another part of the high seas or an exclusive economic zone". These can be regarded as applying a geographic standard and functional standard. ${ }^{39}$ In the international society, there are still debates over which of the two standards take priority, but generally speaking, they serve equal roles. However, in Article 45, there is another rule stating, "The regime of innocent passage, in accordance with Part II, section 3, shall apply in straits used for international navigation: (a) excluded from the application of the regime of transit passage under

\footnotetext{
37 Zou Keyuan, 'Navigation of foreign vessels within China's jurisdictional waters', Maritime Policy \& Management, 2002, 29:4, p.367.

38 Zou Keyuan, ibid.

39 Zou Keyuan, 'Redefining the Legal Status of the Taiwan Strait', International Journal of Marine and Coastal Law, Vol 15, No 2, pp.251-252.
} 
Article 38, paragraph 1; or (b) between a part of the high seas or an exclusive economic zone and the territorial sea of a foreign State.” It seems that there are two different kinds of passages for straits used for international navigation established in the LOSC, one applies to transit passage, another to innocent passage. When noticing the difference between transit passage and innocent passage, it makes more sense why there are two independent rules set here. As Sohn once depicted, 'the rule of thumb is that the closer a ship comes to land, the stronger is the control of the coastal state. ${ }^{40}$

There are three main straits within China's jurisdictional waters, the Taiwan Strait, the Bohai Strait, and the Qiongzhou Strait. As for Qiongzhou Strait, there are specific regulations including the Rules for the Control of Non-Military Vessels of Foreign Origin Passing through the Qiongzhou Strait, ${ }^{41}$ and the Provisions on Administration of Ferry Transport in the Qiongzhou Straits (2005). ${ }^{42}$ The Qiongzhou Strait is situated between the Hainan Island and the Leizhou Peninsula. It is about 50 miles long and extends between 9.8-19 miles wide. In 1958, the PRC promulgated the Declaration on the Territorial Sea, which expressly declared that the Qiongzhou Strait was China's internal strait. The reasons behind this statement were, according to a Chinese authority, that the Qiongzhou Strait 'is an important sea route linking the mainland with the Hainan Island and a convenient navigation route between our country and Southeast Asian countries. It has an extremely important meaning for our economy and national defense. Historically, it has always been subject to our sovereign jurisdiction and has constituted an inalienable, composite part of our territory. Since liberation our country has always administered it as an internal strait. The present Declaration is merely to reaffirm once more a historical fact'. ${ }^{43}$ It should be noted that whether the Qiongzhou Strait was an internal strait of China was unclear before the 1958 Declaration. It may

\footnotetext{
40 L. B. Sohn, 'International navigation: interests related to national security', in J. M.Van Dyke, L. M. Alexander and J. R. Morgan (eds.), International Navigation: Rocks and Shoals Ahead? (Honolulu: Law of the Sea Institute, University of Hawaii, 1988), p.307.

${ }^{41}$ Rules for the Control of Non-Military Vessels of Foreign Origin Passing through the Qiongzhou Strait, 8 June 1964.

42 Provisions on Administration of Ferry Transport in the Qiongzhou Straits, 24 January 2005.

${ }^{43}$ Fu Zhu, 1959, Concerning of Our Country's Territorial Sea (Beijing), reprinted in J. A. Cohen and H. Chiu, People's China and International Law (Princeton, New Jersey: Princeton University Press, 1974), 1, p.486.
} 
be assumed that Qiongzhou Strait's status as an internal strait was to a large extent a result of China's declaration to use straight baselines to enclose the coastal sea areas as its internal waters, although at that time the exact delineation was not publicly known. ${ }^{44}$ Also in the Declaration on the Territorial Sea, Bohai Strait is also considered as China's internal strait.

Thus, the above two straits are not straits used for international navigation, which is completely consistent with the regulation in the LOSC, as these straits are neither "between one part of the high seas or an exclusive economic zone and another part of the high seas or an exclusive economic zone" nor "between a part of the high seas or an exclusive economic zone and the territorial sea of a foreign State".

The Taiwan Strait is located between Taiwan and mainland China constituting a critical corridor, with its widest breadth of 116 nautical miles connecting the East China Sea and the South China Sea. It is an important navigational waterway in East Asia. The navigation in the Taiwan Strait is reflected by two major elements: one is the navigation of foreign vessels and the other is the navigation of the vessels from both sides of the strait under special administration.

As defined in the LOSC, 'the legal status of the waters beyond the territorial seas of States bordering straits' is EEZ or high seas. In history, China declared that there were high seas in the Taiwan Strait, however, since the adoption of the LOSC in 1982, the legal status of the Taiwan Strait has been changed. Under China's domestic legislation, China's EEZ area can cover the whole strait. Therefore, there are internal waters, territorial sea, and EEZ in the Taiwan Strait with each different zone subject to legal governance under relevant Chinese laws and regulations. That is to say, the water area in the Taiwan Strait, which is not part of China's internal waters or of territorial sea, has become part of China's EEZ. Due to the change of the legal status of the Taiwan Strait, the navigation of foreign vessels is no longer subject to the freedom of high seas but rather to the legal regime for the EEZ, although under the LOSC there is no substantive difference in terms of navigation between legal regime for the high seas and

\footnotetext{
${ }^{44}$ Zou Keyuan, 'Navigation of foreign vessels within China's jurisdictional waters', Maritime Policy \& Management, 2002, 29:4, pp.351-374.
} 
that for the EEZ. ${ }^{45}$ Besides, the PRC publicized part of its straight baselines in May 1996 together with its ratification of the LOSC. The publicized baselines include the mainland coast along the Taiwan Strait. If there is a navigational route inside the publicized baselines, then the PRC has the full control over the passage of foreign vessels. ${ }^{46}$ However, in the international law of the sea, there is still no definite rules governing straits within the coastal state's EEZ.

Article 35 of the LOSC stipulates that 'Nothing in this Part affects: (a) any areas of internal waters within a strait, except where the establishment of a straight baseline in accordance with the method set forth in Article 7 has the effect of enclosing as internal waters areas which had not previously been considered as such; (b) the legal status of the waters beyond the territorial seas of states bordering straits as exclusive economic zones or high seas; or (c) the legal regime in straits in which passage is regulated in whole or in part by long-standing international conventions in force specifically relating to such straits.'

According to Article 35, straits used for international navigation must be within the territorial seas of the coastal states. Specifically, clause (b) of this Article excludes the Taiwan Strait from the straits used for international navigation. Thus, the Taiwan Strait is not a strait used for international navigation as defined in the LOSC, so that the 'transit passage' regime under the Convention does not apply to the Taiwan Strait.

Another factor that makes the Taiwan Strait complicated is the cross-Strait relations resulting from the divided situation of China: the PRC on mainland China and the ROC on Taiwan, due to the Chinese civil war in the late 1940s. The two sides each have laws and regulations of its own. Lack of a clear demarcation line of jurisdiction between the two sides resulted in overlapping areas claimed by both sides for their jurisdiction, which can cause problems for the navigation of foreign vessels in the Taiwan Strait, particularly in its EEZ part. As the PRC and ROC do not regard each other as foreign states, there are special rules made by both sides to govern the

\footnotetext{
45 Zou Keyuan, 'Navigation of foreign vessels within China's jurisdictional waters', Maritime Policy \& Management, 2002, 29:4, p.365.

46 Zou Keyuan, 'Redefining the Legal Status of the Taiwan Strait', International Journal of Marine and Coastal Law, Vol 15, No 2, p.252.
} 
navigation of PRC and ROC vessels, such as the Provisions Governing the Administration of the Direct Shipping between the Two Sides of the Taiwan Strait issued under Decree No.6 of the Ministry of Communications of the PRC in $1996,{ }^{47}$ in which shipping between the two sides is defined as 'domestic transportation under special administration'. Therefore, the mainland China will not agree to the grant to foreign vessels the right of cabotage. ${ }^{48}$

In 2002, the Ministry of Communication published the Notice of the Ministry of Communications on Strengthening the Administration of Tramp Ship Transport across the Taiwan Strait. ${ }^{49}$ The Notice provides that in accordance with the Measures for the Administration of Shipping Across the Taiwan Strait promulgated by the Ministry of Communications in August 1996 and the Regulations of the People's Republic of China on International Shipping promulgated by the State Council in December 2001, no enterprise or ship may, without the approval of the communications authority under the State Council, operate water transport straight from China's mainland to Taiwan area or vice versa, or through a third place. And the Notice gives detailed information and requirements on Administration of Tramp Ship Transport across the Taiwan Strait.

\section{Hong Kong Practice}

Law application in Hong Kong is much simpler than Taiwan to the mainland. After 1997, China resumed control of Hong Kong, this landmark event marked the end of British rule in Hong Kong, and the beginning of China's sovereignty over Hong Kong. Basic issues regarding China's basic policies to Hong Kong are stipulated in the Hong Kong Basic Law. After the handover, although Hong Kong's constitutional order has

\footnotetext{
47 Provisions Governing the Administration of the Direct Shipping between the Two Sides of the Taiwan Strait issued under Decree No.6 of the Ministry of Communications of the PRC.

48 Zou Keyuan, 'Navigation of foreign vessels within China's jurisdictional waters', Maritime Policy \& Management, 2002, 29:4, pp.351-374.

49 Notice of the Ministry of Communications on Strengthening the Administration of Tramp Ship Transport across the Taiwan Strait, date issued, 26 November 2002.
} 
been changed ${ }^{50}$, it remained a common law jurisdiction, with a separate legal system from that used in the mainland, with previous laws remaining in force provided that they did not conflict with the Basic Law. ${ }^{51}$

The Port of Hong Kong has always been a key factor in the economic development of the Hong Kong SAR (Special Administrative Region). It is a hub port serving the South Asian Pacific region and acts as an entreport for the Mainland of China. It is one of the busiest container ports in the world. In terms of vessel arrivals and departures, and cargo and passenger throughput, it is also one of the major ports of the world. ${ }^{52}$ The administrative department of the port is the Marine Department of the Hong Kong SAR, and its principal functions are to ensure safe operation of the port and all Hong Kong waters as well as to operate the Hong Kong Shipping Register and safeguard the quality of the Hong Kong registered ships. ${ }^{53}$

The Marine Department has established a systematic and comprehensive legal system to govern navigation. These shipping ordinances and their subsidiary legislation include, Port Control (Cargo Working Areas) Ordinance, Pilotage Ordinance, Merchant Shipping Ordinance, Shipping and Port Control Ordinance, Marine Insurance Ordinance, Merchant Shipping (safety) Ordinance, Merchant Shipping (Liability and Compensation for Oil Pollution) Ordinance, Merchant Shipping (Registration) Ordinance, Merchant Shipping (Limitation of Ship-owners Liability) Ordinance, Carriage of Goods by Sea Ordinance, Merchant Shipping (Seafarers) Ordinance, Merchant Shipping (Liner Conferences) Ordinance, Freight Containers (safety) Ordinance, Merchant Shipping (Collision Damage Liability and Salvage) Ordinance, Merchant Shipping (Local Vessels) Ordinance, Merchant Shipping (security of Ships and Port Facilities) Ordinance, Bunker Oil Pollution (Liability an Compensation) Ordinance, Dangerous Goods Ordinance, Mercantile Marine Assistance Fund

\footnotetext{
50 Yash Ghai, Hong Kong's New Constitutional Order: The Resumption of Chinese Sovereignty and the Basic Law, Hong Kong University Press, 1997, p.167.

51 China Briefing's Business Guide to the Greater Pearl River Delta, China Briefing Media, Ltd., 2004, p. 245.

52 http://www.mardep.gov.hk/en/aboutus/home.html.

53 http://www.mardep.gov.hk/en/aboutus/home.html.
} 
Ordinance, Sailors Home and Missions to Seamen Incorporation Ordinance. ${ }^{54}$ From the legislation of the Marine Department, we can see that the Hong Kong government focuses more on regulation of merchant shipping and navigation in this area instead of other activities such as fishing or military activities. As Hong Kong is an integrated part of People's Republic of China, the general legislation of China as previously discussed, including the Law on the Territorial Sea and Contiguous Zone and Law of the Exclusive Economic Zone and Continental Shelf, applies to other activities in the Hong Kong area.

\section{Navigation in the EEZ}

\section{Regulation on Vessel-Source Pollution within the EEZ}

The most important and comprehensive legislation concerning China's maritime environment protection is the Marine Environment Protection Law, which explicitly regulates jurisdiction related issues of pollution resulting from foreign vessels. Article 62(1) provides, 'No vessels and their related operations shall, in the sea areas under the jurisdiction of the People's Republic of China, discharge pollutants, wastes, ballast water, vessel garbage and other harmful substances into the sea in violation of the provisions of this law. ${ }^{55}$ On 2 September 2009, the State Council deliberated and passed the Regulations on the Prevention and Control of Vessel-induced Pollution to the Marine Environment, further defined and detailed jurisdiction related issues of pollution resulting from foreign vessels.

The Marine Environment Protection Law is ranked as law, whereas the Regulations on the Prevention and Control of Vessel-induced Pollution to the Marine Environment is ranked as administrative regulations. According to the principle of legally prescribed punishment for a specified crime, the former legislation is the main source of this area. And an important related clause is Article 91(3) which provides, 'Those who causes serious consequences of heavy losses of public and private property

\footnotetext{
${ }^{54} \mathrm{http} / / /$ www.mardep.gov.hk/en/publication/home.html.

${ }^{55}$ Marine Environment Protection Law, Article 62(1).
} 
or human injuries and deaths of persons by major marine environment pollution accident, shall be investigated and imposed upon criminal responsibility by law. ${ }^{56}$ As for specific penalty, Article 338 of the Criminal Law of the People's Republic of China provides related reference. ${ }^{57}$

What we can notice is that China's legislations regulating foreign vessel related marine pollution do not strictly differentiate different maritime zones, simply with a set of general rules governing all China's maritime zones.

\section{Military Vessels}

The LOSC does not provide specific regulations on whether foreign vessels can engage in military activities within a coastal state's EEZ. China gives some general requirements in its Law on the Exclusive Economic Zone and the Continental Shelf. Article 11 provides, 'All states shall, on the premise that they comply with international law and the laws and regulations of the People's Republic of China, enjoy the freedom of navigation in and flight over its exclusive economic zone, the freedom to lay submarine cables and pipelines and the convenience of other lawful uses of the sea related to the freedoms mentioned above in the exclusive economic zone and on the continental shelf of the People's Republic of China' ${ }^{58}$ Based on recent practices, China expects foreign vessels present within China's EEZ to comply with Chinese domestic law.

For example, the USNS Impeccable (T-AGOS 23) engaged in military activities in China's EEZ. On 8 March 2009, five PRC vessels stopped the Impeccable. The U.S. government protested that the PRC's action was reckless, unprofessional, and unlawful. China responded that the Impeccable's presence in China's EEZ was in violation of Chinese domestic law and international law. ${ }^{59}$ China's interception of the USNS

\footnotetext{
56 Marine Environment Protection Law, Article 91(3).

57 Criminal Law of the People's Republic of China, Article 338.

58 Law on the Exclusive Economic Zone and the Continental Shelf of the People's Republic of China, Article 11.

59 On 10 March, Chinese Foreign Ministry spokesman Ma Zhaoxu said that the LOSC and the Law on the Exclusive Economic Zone and the Continental Shelf of the People's Republic of China, the Provisions of the People's Republic of China on Administration of Foreign-related Marine Scientific Research all provide related regulations on activities of foreign vessels within the EEZ. The Chinese government consistently practices according to these laws. The USNS Impeccable operated within China's EEZ without permission, which violated international law and
} 
Impeccable does not mean that Chinese government absolutely excludes military vessels from navigating in China's EEZ; instead, China requires foreign military vessels and government vessels when passing through China's EEZ to obey China's domestic law, respect China's security interest, and not undertake activities that may threaten China's national security. ${ }^{60}$

Article 9 of China's EEZ Law provides, 'All international organizations, foreign organizations or individuals that wish to conduct marine scientific research in the exclusive economic zone or on the continental shelf of the People's Republic of China shall be subject to approval of the competent authorities of the People's Republic of China and shall comply with the laws and regulations of the People's Republic of China.' From this article, we can conclude that military vessels' rights are limited when conducting scientific research. This means that China does not give absolute freedom to military vessels operating in its EEZ.

Also, Article 12 of the same Law provides, 'The People's Republic of China may, in the exercise of its sovereign rights to explore its exclusive economic zone and to exploit, conserve and manage the living resources there, take such necessary measures as visit, inspection, arrest, detention and judicial proceedings in order to ensure that the laws and regulations of the People's Republic of China are complied with. The People's Republic of China has the right to take necessary measures against violations of its laws and regulations in its exclusive economic zone and on its continental shelf and to investigate for legal responsibility according to law, and may exercise the right of hot pursuit.' This article gives further legal basis for the interception of the Impeccable.

The Impeccable-like military demonstration has increased in the South China Sea since Trump came to power. In our view, the conflicts between the U.S. and China are rooted in the different understandings of the freedom of the seas. For the U.S., the freedom of the seas is a more absolute concept. But for China, it is conditional, and when the freedom is in conflict with state sovereignty or national security, it should

\footnotetext{
China's domestic law, available at http://mil.news.sina.com.cn/2009-03-16/1540545587.html.

60 For more reference, see Zou Ligang, 'A Discussion on China's Power to Govern Foreign Countries' Military in the Exclusive Economic Zone', China Legal Science, 2012, No.6.
} 
give way.

\section{Fishing Vessels}

The Law on the Exclusive Economic Zone and the Continental Shelf provides general rules on administrative enforcement actions against foreign fishing vessels within China's EEZ. China does not have an integrated set of regulations on maritime resources, instead, it has several independent laws and administrative rules regulating these issues, such as the Fisheries Law, ${ }^{61}$ the Measures for the Management of Marine Nature Reserves, ${ }^{62}$ the Regulations of Pelagic Fishery. ${ }^{63}$ Furthermore, in order to better provide detailed guiding rules, the Ministry of Agriculture enacted more measures including the Interim Measures on Management of Foreigners ${ }^{64}$, Foreign Ships' Activity within Waters of People's Republic of China, ${ }^{65}$ and the Provisions on the Administration of Fishery Administrative Cruising within the Exclusive Economic Zone. ${ }^{66}$

The Interim Measures on Management of Foreigners, Foreign Ships' Fishing Activity within the Waters of the People's Republic of China gives detailed regulations on procedure (Article 5-7), rules involving foreigners and foreign fishery vessels navigating in China's EEZ, and related penalties for illegal navigation (Article 11-20). For China, the right of navigation and state sovereignty over natural resources within its maritime area are never separated issues, and foreign vessels' right of navigation may be compromised by state sovereignty over natural resources, such as the management and conservation measures of fishing. The laws mentioned above are among those that may influence foreign fishing vessels' right of navigation, which is justified in the international law of the sea.

\footnotetext{
61 Fisheries Law of the People's Republic of China, 28 December 2013.

62 Measures for the Management of Marine Nature Reserves.

63 Regulations of Pelagic Fishery.

64 Interim Measures on Management of Foreigners.

65 Foreign Ships' Activity within Waters of People's Republic of China.

66 Provisions on the Administration of Fishery Administrative Cruising within the Exclusive Economic Zone, 14 November 2005.
} 


\section{Scientific Research Vessels}

As stated above, Article 9 of Law on the Exclusive Economic Zone and the Continental Shelf provides, 'All international organizations, foreign organizations or individuals that wish to conduct marine scientific research in the exclusive economic zone or on the continental shelf of the People's Republic of China shall be subject to approval of the competent authorities of the People's Republic of China and shall comply with the laws and regulations of the People's Republic of China'. As for the activity of surveying and mapping, there is a specific regulation. In the Surveying and Mapping Law of the People's Republic of China, ${ }^{67}$ Article 7 stipulates, 'A foreign organization or individual that conducts surveying and mapping in the territorial air, land and waters, as well as other sea areas under the jurisdiction of the People's Republic of China must be subject to the approval of the department of surveying and mapping administration under the State Council jointly with the department of surveying and mapping administration in the armed forces, and must abide by the relevant laws and regulations of the People's Republic of China. A foreign organization or individual that conducts surveying and mapping in the territorial air, land and waters of the People's Republic of China must take the form of an equity joint venture or contractual joint venture with the relevant departments or entities of the People's Republic of China, and may not involve any state secret or harm the state security'.

In practice, the situation concerning marine scientific research is more complicated and China has concerns for its national security. For example, China opposed to the US military vessels operating in China's EEZ in the name of marine scientific research. Although the LOSC does not explicitly provide any regulations on foreign vessel's military activity in coastal state, one thing is clear that international law respects sovereign state's right to protect national security, especially military security.

67 Surveying and Mapping Law of the People's Republic of China, 29 August 2002. 


\section{IMO Approved Routeing Arrangements}

As we know, the Chengshanjiao routeing system is the first and the only routeing system of China adopted by the IMO. Facing high speed development of waterborne transportation, China is challenged by a serious loss of lives and properties, and by marine environmental pollution. In response, China has taken various measures to solve these problems. Establishing routeing systems in Chinese waterways is an important one.

In Chinese navigable waters, there are five key areas, in which, shipping density is high, sea routes are crossing, traffic is congested, and maritime accidents occur frequently. They include Bohai Strait (Laotieshang Channel), Chengshanjiao waters, Changjiangkou waters, Zhujiangkou waters and Qiongzhou Strait. ${ }^{68}$ The earliest ships routeing measure which introduced in the 1970s on an optional basis was the recommended routeing measure, named as the South-North Route between Changjiangkou waters and Bohai Sea, which was established to separate optional traffic flow so as to avoid collisions. The arrangement of the South-North Route drew rich navigational experiences and good seamanship from other parts of the world, and made reference to the traffic separate scheme implemented in the Dover Strait. ${ }^{69}$

Since 2002, there have been many routeing systems developed and implemented, such as the Changjiangkou routeing system implemented in September 2002; the Changjiang Jiangsu routeing system in July 2003; the Zhujiangkou routeing system implemented in March 2004; Changjiang Anhui routeing system implemented in October 2005; the Changjiang Shanghai routeing system implemented in March 2006; the Laotieshan Channel routeing system implemented in June 2006; the Qiongzhou Strait routeing system implemented in January 2007; and the Changjiang Sanxia routeing system implemented in December 2005. ${ }^{70}$

In 2011, the Ministry of Communications published the general plans for the

\footnotetext{
$68 \mathrm{H} \mathrm{Ma}$, Z. Wu, and Z. Liu, 'New Development of Ships Routeing in Chinese Navigable Waterways', International Journal on Marine Navigation and Safety of Sea Transportation, 2008, Vol. 2, No. 2, pp. 127-130.

69 Ibid.

70 Ibid.
} 
national coastal shipping routeing system, and the general plans for coastal routes, setting the goal of establishing 26 routeing systems in China in 3 to 5 years, so as to finally achieve 'waterborne highways'. Within the past few years, China not only established new routeing systems, it also kept adapting existing rules according to industrial development. For example, as the 2000 Chengshanjiao ship routeing system can no longer satisfy cotemporary requirement for shipping, China submitted two proposals to IMO for revising "Chengshanjiao ship routeing system" and “Chengshanjiao ship reporting system" in June 2014. The proposals were approved by IMO, and in April 2015, the Ministry of Communications published related documents, finally, the two systems went into force on 1 July 2015.

\section{Conclusion}

Although the regulations mentioned above in China are comprehensive and generally in conformity with the LOSC and/or other applicable international rules, they are far from adequate or perfect. China needs to fulfill its obligations within the LOSC to establish explicit and detailed rules ensuring foreign vessels' right of innocent passage in accordance with the LOSC. China has no archipelagic sea lane passage. Controversies between China and the Philippines in the South China Sea resulting from straight baseline issues are mainly about territorial disputes, instead of different interpretations of 'archipelagic sea lane passage' under the LOSC. According to the LOSC, the Taiwan Strait is not a strait used for international navigation, so that the 'transit passage' regime under LOSC does not apply to it. However, China needs more regulations governing this waterway because of the complicated situation of "crossstrait" relations between mainland China and Taiwan.

China's EEZ-related legislations cover the fields like vessel-source pollution within the EEZ, fishing vessel navigation; however, regulations on military vessel navigation and military activities are still not adequate. Although China has established many ship roueting systems in various waters, it still needs to adapt to ever changing 
situation and requirement. Existing rules need to be revised in time or in advance when necessary to meet the above changes. 